2016

\title{
Everyday Legal Problems and the Cost of Justice in Canada: Overview Report
}

Trevor C. W. Farrow

Osgoode Hall Law School of York University, tfarrow@osgoode.yorku.ca

$\mathrm{Ab}$ Currie

Canadian Forum on Civil Justice of York University, abcurrie@sympatico.ca

Nicole Aylwin

Winkler Institute for Dispute Resolution of York University, naylwin@cfcj-fcjc.org

LesleyJacobs

York University, jacobs@yorku.ca

David Northrup

northrup@yorku.ca

See next page for additional authors

Follow this and additional works at: http:// digitalcommons.osgoode.yorku.ca/olsrps

Part of the Law and Society Commons

\section{Recommended Citation}

Farrow, Trevor C. W.; Currie, Ab; Aylwin, Nicole; Jacobs, Lesley; Northrup, David; and Moore, Lisa, "Everyday Legal Problems and the Cost of Justice in Canada: Overview Report" (2016). Osgoode Legal Studies Research Paper Series. 150.

http://digitalcommons.osgoode.yorku.ca/olsrps/150 
Authors

Trevor C. W. Farrow, Ab Currie, Nicole Aylwin, Lesley Jacobs, David Northrup, and Lisa Moore 


\title{
OSGOODE HALL LAW SCHOOL \\ LEGAL STUDIES RESEARCH PAPER SERIES
}

Research Paper No. 57

Volume 12, Issue 12, 2016

\section{Everyday Legal Problems and the Cost of Justice in Canada: Overview Report Canadian Forum on Civil Justice, 2016.}

\author{
Trevor C.W. Farrow \\ Ab Currie \\ Nicole Aylwin \\ Les Jacobs \\ David Northrup \\ Lisa Moore
}

This paper can be downloaded free of charge from:

http://ssrn.com/abstract $=2795672$

\begin{abstract}
Further information and a collection of publications from the Osgoode Hall Law School Legal Studies Research Paper Series can be found at:

http://www.ssrn.com/link/Osgoode-Hall-LEG.html
\end{abstract}

\section{Editors:}

Editor-in-Chief: Carys J. Craig (Associate Dean of Research \& Institutional Relations and Associate Professor, Osgoode Hall Law School, York University, Toronto)

Production Editor: Antonnia Kiana Blake (Osgoode Hall Law School, York University, Toronto) 
Osgoode Legal Studies Research Paper No. 57

Vol. 12/ Issue. 12/ (2016)

\title{
Everyday Legal Problems and the Cost of Justice in Canada: Overview Report
}

Canadian Forum on Civil Justice, 2016.

\author{
Trevor C.W. Farrow \\ Ab Currie \\ Nicole Aylwin \\ Les Jacobs \\ David Northrup \\ Lisa Moore
}

\author{
Author(s): \\ Trevor C.W. Farrow \\ Professor and Associate Dean \\ Osgoode Hall Law School, York University \\ E: tfarrow@osgoode.yorku.ca
}

Ab Currie

Senior Research Fellow

Canadian Forum on Civil Justice

E: abcurrie@sympatico.ca

Nicole Aylwin

Assistant Director

Winkler Institute for Dispute Resolution

E: naylwin@cfcj-fcjc.org

Les Jacobs

Professor

York University

E: jacobs@yorku.ca

David Northrup

Director, Survey Research of the Institute for Social Research

York University

E: northrup@yorku.ca

Lisa Moore

Operations Director and Research Coordinator

Canadian Forum on Civil Justice

E: Imoore@cfcj-fcjc.org 


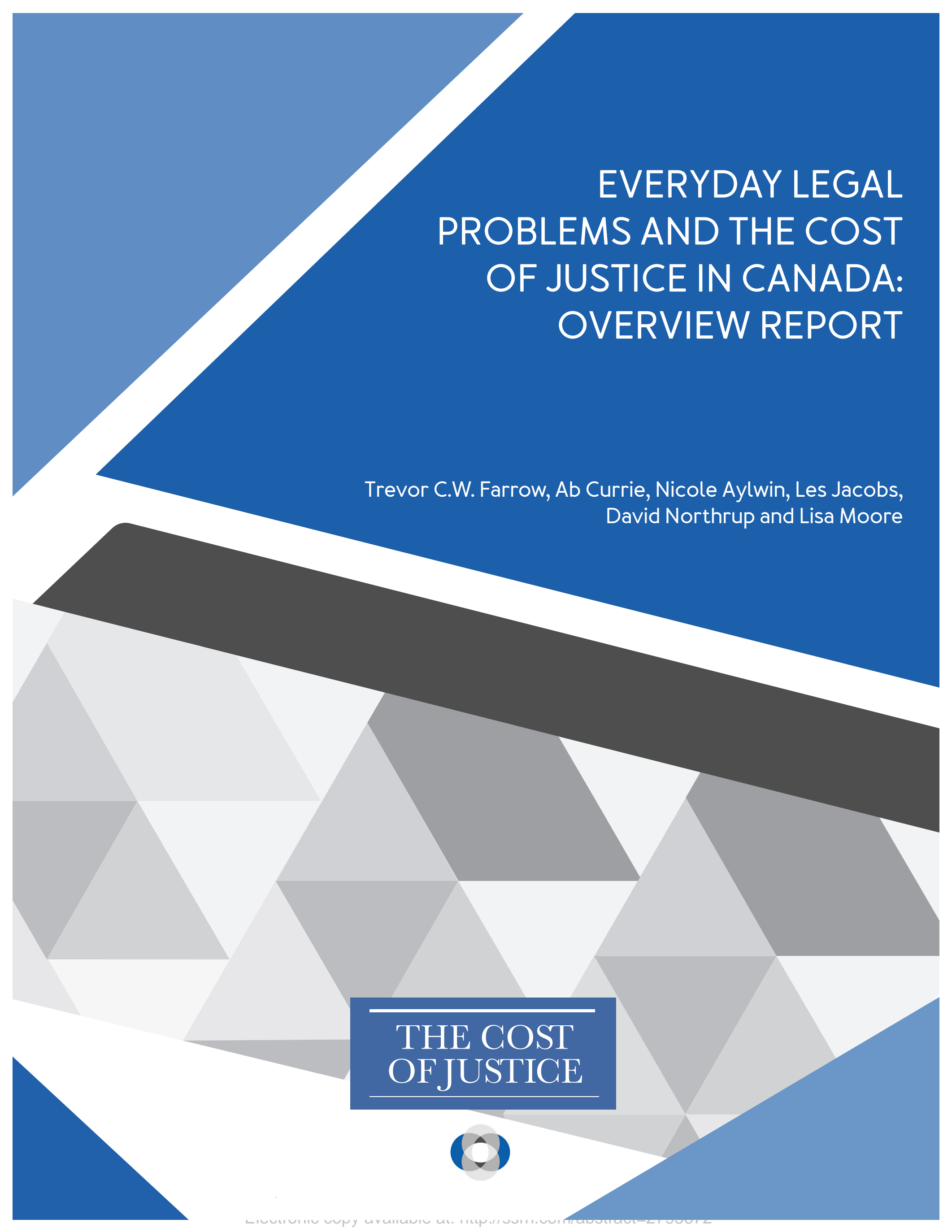




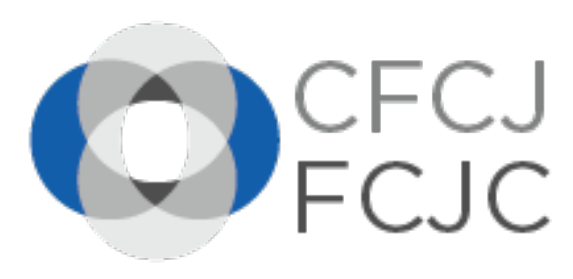

Canadian Forum on Civil Justice * Forum canadien sur la justice civile

"This research ... by the Canadian Forum on Civil Justice will be essential in helping us understand the true extent of the problem of cost and how it impacts on the justice system. I believe that it will prove to be of great assistance to ... identify concrete solutions to the problem of access to justice."

- The Right Honourable Beverley McLachlin, P.C., Chief Justice of Canada (2011)

The Canadian Forum on Civil Justice is a national not-for-profit organization dedicated to civil justice reform and access to justice research and advocacy. Established by the Canadian Bar Association and affiliated with Osgoode Hall Law School, the CFCJ envisions an accessible, sustainable and effective justice system for all Canadians.

Overview of the Cost of Justice project. The Cost of Justice project (2011-2017) examines the social and economic costs of Canada's justice system. It is guided by two questions: What is the cost of delivering access to justice? And what is the cost of not delivering access to justice? Comprised of leading researchers investigating various dimensions of access to justice and cost across the country, the Cost of Justice project is producing empirical data that will inform the future of access to justice in Canada and abroad. The lead research team includes: Trevor C.W. Farrow (Principal Investigator), Nicole Aylwin, Les Jacobs, Lisa Moore, and Diana Lowe.

The Cost of Justice project is funded by a \$1 million grant from the Social Sciences and Humanities Research Council of Canada. For more details please visit Canadian Forum on Civil Justice, "Cost of Justice", online: CFCJ $<$ www.cfcj-fcjc.org/cost-of-justices.

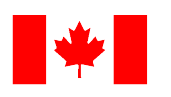

Social Sciences and Humanities Research Council of Canada
Conseil de recherches en sciences humaines du Canada
Canadä̀ 


Almost half
$(48.4 \%)$ of
Canadians over 18
will experience at
least one civil or
family justice
problem over any
given three-year
period.

Almost half

Canadians over 18

will experience at

least one civil or

family justice

problem over any

period.

\section{EVERYDAY LEGAL PROBLEMS AND THE COST OF JUSTICE IN CANADA: OVERVIEW REPORT}

Trevor C.W. Farrow, Ab Currie, Nicole Aylwin, Les Jacobs, David Northrup and Lisa Moore*

\section{Introduction $^{1}$}

Law and legal problems are part of everyday life. If you have ever been harassed at work, unfairly fired or evicted, divorced, not received support payments, disputed a will or a cell phone contract, or had your credit rating challenged, you may have already experienced one of these types of everyday legal problems. If so, you are not alone. Almost half (48.4\%) of Canadians over 18 will experience at least one civil or family justice problem over any given three-year period. Even though many Canadians do not understand, feel connected to or welcomed by the justice system, ${ }^{2}$ essentially all of us will experience at least one everyday legal problem over the course of our lifetime.

\footnotetext{
* Trevor C.W. Farrow is a Professor and Associate Dean at Osgoode Hall Law School, the Academic Director of the Winkler Institute for Dispute Resolution, and the Chair of the Canadian Forum on Civil Justice. Ab Currie is a Senior Research Fellow at the Canadian Forum on Civil Justice. Nicole Aylwin is the Assistant Director of the Winkler Institute for Dispute Resolution and a Research Fellow at the Canadian Forum on Civil Justice. Les Jacobs is a Professor of Law \& Society and Political Science at York University, the Director of the Institute for Social Research at York University, and a Senior Research Fellow at the Canadian Forum on Civil Justice. David Northrup is the Director, Survey Research of the Institute for Social Research at York University. Lisa Moore is the Operations Director and Research Coordinator at the Canadian Forum on Civil Justice.

${ }^{1}$ This overview report - based on data analysis primarily conducted by Ab Currie, as supported by David Northrup and the balance of our research team - summarizes some of the basic findings of the Canadian Forum on Civil Justice's 2014 "Everyday Legal Problems and the Cost of Justice in Canada" survey. This overview report builds on, and in some cases updates and clarifies, some of the preliminary findings released in our initial reporting on this survey (see e.g. Canadian Forum on Civil Justice, "Everyday Legal Problems and the Cost of Justice in Canada: Fact Sheet" (12 March 2015), online: <http://www.cfcj-fcjc.org/a2jblog/everyday-legalproblems-and-the-cost-of-justice-in-canada>).

2 Trevor C.W. Farrow, "What is Access to Justice?" 51:3 (2014) Osgoode Hall LJ 957 at 974.
} 


\section{The "Everyday} Legal Problems and the Cost of Justice in Canada" survey is the first Canadian study of its kind to ask the public what legal problems cost not just in dollars, but in time and opportunity costs, costs to their physical and mental health, and costs to their livelihood.
Canada has one of the best legal systems in the world: independent judges, well-trained lawyers, predictable laws, and an open court process. ${ }^{3}$ Unfortunately, most Canadians cannot afford to use it. Largely because of cost, very few Canadians will be able to afford to resolve these types of legal problems - particularly if they try to use the formal justice system. Getting legal help is expensive. Average hourly legal fees can amount to hundreds of dollars. ${ }^{4}$ If you do need to go to court, a relatively short proceeding can cost tens of thousands of dollars. ${ }^{5}$ Legal aid is only available for the very needy and even then, not for many everyday legal problems. ${ }^{6}$

Yet, other than knowing that most people cannot afford the legal system, we know very little about the specific costs of justice - how to measure, manage and reduce those costs, what it would cost to provide increased amounts of public legal services, what it would cost to help prevent legal problems from occurring in the first place, or what the relative costs and savings of doing so might be. We know even less about the important connections between affordable justice services and our individual and collective wellbeing.

\section{National Legal Problems Survey}

In an attempt to advance our understanding of the costs of justice, the Canadian Forum on Civil Justice recently conducted a national legal-problems survey that examines the everyday legal problems experienced by the Canadian public. The "Everyday Legal Problems and the Cost of Justice in

\footnotetext{
${ }^{3}$ See e.g. World Justice Project, Rule of Law Index 2015 (Washington, D.C.: World Justice Project, 2015) at 6, online: <http://worldjusticeproject.org/sites/default/files/roli_2015_0.pdf> (Canada is given a global ranking of 14).

${ }^{4}$ See e.g. Michael McKiernan, "On the Upswing" (July 2014) Canadian Lawyer 32, online: <http://www.canadianlawyermag.com/images/stories/pdfs/Surveys/2014/Comp_Survey.pdf> (reviewing Canadian Lawyer's "2014 Compensation Survey"). For a recent discussion, see Noel Semple, "The Cost of Seeking Civil Justice in Canada" (2015) 93 Can. Bar Rev. 639 at 650-654.

${ }^{5}$ For a general discussion, see Action Committee on Access to Justice in Civil and Family Matters, Access to Civil \& Family Justice: A Roadmap for Change (Ottawa: Action Committee on Access to Justice in Civil and Family Matters, October 2013) at 2-5 (and references), online: CFCJ $<$ http://www.cfcj-fcjc.org/sites/default/files/docs/2013/AC_Report_English_Final.pdf>. See recently Semple, "The Cost of Seeking Civil Justice in Canada", ibid. at 654-658.

${ }^{6}$ See e.g. Action Committee on Access to Justice in Civil and Family Matters, Access to Civil \& Family Justice: A Roadmap for Change, ibid. at 2-5.
} 
Canada" survey is the first national survey in nearly ten years to measure the frequency, and ways in which members of the Canadian public experience everyday legal problems. ${ }^{7}$ Further, it is the first Canadian study of its kind to ask the public what these problems cost - not just in dollars, but in time and opportunity costs, costs to their physical and mental health, and costs to their livelihood. ${ }^{8}$

This study is based on a national random sample of over 3,000 Canadians aged 18 years of age and older conducted through telephone interviews between September 2013 and May 2014. ${ }^{9}$ The purpose of the study was to

7 For a recent discussion of other legal needs surveys, see Nicole Aylwin and Mandi Gray, "Selected Annotated Bibliography of National and Regional Legal Needs Surveys" (Toronto: Canadian Forum on Civil Justice, 2015), online: CFCJ

<http://www.cfcj-fcjc.org/sites/default/files//CFCJ\%20Cost\%20of\%20Justice\%20Project\%20$\% 20$ Selected\%20Annotated\%20Bibliography.pdf>.

${ }^{8}$ Up to the present, legal problems research has focused primarily on the prevalence of everyday legal problems, the occurrence of multiple problems and problem clusters, what people do about legal problems, the extent to which people get the help they need and what happens when they do not. The "Everyday Legal Problems and the Cost of Justice" survey is the first legal problems survey in Canada to ask extensive questions about the monetary costs associated with experiencing everyday legal problems. Questions were asked about the monetary costs to individuals of attempting to resolve problems, intangible costs associated with experiencing legal problems in terms of physical health problems, high levels of stress and emotional problems, and the loss of security of the person due to loss of employment or housing. In sum, respondents were asked about costs they felt were directly related to experiencing legal problems.

9 The random telephone survey included 3,051 adults living in households with land lines and 212 adults using cell phones (for a total of 3,263 adult Canadians). For the purpose of this overview report, the results presented here are based on the land line calls (3,051 people). The Institute for Social Research at York University conducted the telephone interviews. The results are accurate within a 1.8\% margin of error (meaning that if the survey were repeated 100 times the results would be the same $95 \%$ of the time for a variable with a binary response and a 50/50 distribution). The sample completion rate was $42 \%$, which is a typical - and certainly substantial - rate by industry standards. Respondents were asked if within three years of the interview they had experienced any problems from a list of 84 specific problem scenarios, each one carefully worded to ensure that the issue had legal content. For purposes of the survey, respondents were not expected to recognize the legal implications of the problems or to use any part of the formal justice system to resolve them. The problems were ultimately organized into 17 problem types (as further discussed below - see Figure I). Threshold language in the questions encouraged respondents to report only problems they considered to be serious and difficult to resolve. Subsequent parts of the survey asked about actions taken in response to problems, consequences of experiencing problems, the types and adequacy of assistance received, and connections between problems and the costs related to experiencing everyday legal problems. In order to limit the time required to conduct the telephone survey (making it more manageable for both researchers and respondents), detailed questions about the respondents' experience with legal problems were asked only about the first and second problems. For a more detailed 


\section{An everyday legal problem is a problem arising out of the normal activities of people's daily lives that has a legal aspect and has a potential legal solution.}

\section{A defining feature of this research is that it looks at legal problems from the point of view of the people experiencing} them. examine the public's experiences with the justice system, and in particular, the kinds, methods of dealing with, and costs associated with everyday legal problems in Canada. An everyday legal problem is a problem arising out of the normal activities of people's daily lives that has a legal aspect and has a potential legal solution. The problem is therefore justiciable and could be resolved within the formal legal system, although it may be more sensibly dealt with in other ways. ${ }^{10}$ A defining feature of this research is that it looks at legal problems from the point of view of the people experiencing them. Put simply, it takes a "public first" perspective. ${ }^{11}$ The study was designed with a methodology that is generally consistent with other national legal needs studies conducted in Canada and elsewhere, ${ }^{12}$ primarily so as to yield weighted data that is not only instructive on its own, ${ }^{13}$ but also that is useful from a comparative perspective.

discussion of our approach and methodology, see David Northrup et al., "Design and Conduct of the Cost of Justice Survey" (Toronto: Canadian Forum on Civil Justice, 2016) (forthcoming).

10 This approach follows the definition of a justiciable event developed by Hazel Genn in her Paths to Justice study: "a matter experienced by a respondent which raised legal issues, whether or not it was recognized by the respondent as being 'legal' and whether or not any action taken by the respondent to deal with the event involved the use of any part of the civil justice system." Hazel Genn, Paths to Justice: What People Do and Think about Going to Law (Oxford: Hart, 1999) at 12. See also Ab Currie, The Legal Problems of Everyday Life: The Nature, Extent and Consequences of Justiciable Problems Experienced by Canadians (Ottawa: Justice Canada, 2009) at 5-6; Pascoe Pleasence et al., Causes of Action: Civil Law and Social Justice (Norwich: Stationary Office, 2004) at 1; Christine Coumarelos et al., Legal Australia-Wide Survey: Legal Need in Australia (Sydney: Law and Justice Foundation of New South Wales, 2012).

${ }^{11}$ For recent discussions of this approach, see Trevor C.W. Farrow, "A New Wave of Access to Justice Reform in Canada" in Adam Dodek and Alice Woolley, eds., In Search of the Ethical Lawyer: Stories from the Canadian Legal Profession (Vancouver: UBC Press, 2016) 164 at 167; Farrow, "What is Access to Justice?", supra note 2. See generally Action Committee on Access to Justice in Civil and Family Matters, Access to Civil \& Family Justice: A Roadmap for Change, supra note 5; Canadian Bar Association, Reaching Equal Justice: An Invitation to Envision and Act (Ottawa: Canadian Bar Association, November 2013), online: CBA < http://www.cba.org/CBAEqual-Justice>.

12 For a recent collection of other relevant domestic and international studies, see Aylwin and Gray, "Selected Annotated Bibliography of National and Regional Legal Needs Surveys", supra note 7.

${ }^{13}$ The data used in this report is weighted to correct for unequal probabilities of selection and to correct for variation in response by age and gender. The weights ensure that the proportion of cases in each province, by household size (for example one, two, three, etc. adult households) and by ten different age and gender categories (for example males under 36, females under 36, etc.) match those of the Canadian population. Further, the complex sample routine in SPSS (CSPlan) has been used for this analysis. Use of the Weight Cases command in SPSS with the variable "weight_to_pop" will produce nearly identical results for point estimates but incorrect 


\section{Within a three- year period, approximately 11.4 million adult Canadians will experience at least one everyday legal problem that they consider to be serious and difficult to resolve.}

In this overview report we provide a snapshot of some of our survey results as they pertain to the individual experiences and costs of everyday legal problems experienced by the public. We plan to release follow-up reports addressing the costs of everyday legal problems in the context of several public services and the state, and further, other reports designed to further contextualize our survey results, explain the survey methodology, analyze the data, and develop the implications of our results for policy makers looking to improve access to justice. We will also be releasing several reports that focus on the national and regional findings that we think will have the greatest immediate impact on Canadians. ${ }^{14}$

\title{
The Everyday Legal Problems of Canadians
}

This survey confirms the growing sense that we are experiencing an access to justice crisis in Canada. ${ }^{15}$ Within a three-year period, $48.4 \%$ of the adult Canadian population - or approximately 11.4 million adult Canadians - will experience at least one everyday legal problem that they consider to be serious and difficult to resolve. ${ }^{16}$ Further, many people will experience

estimates for standard errors. For a further detailed description of the survey methodology, see Northrup et al., "Design and Conduct of the Cost of Justice Survey", supra note 9.

\begin{abstract}
${ }^{14}$ See e.g. the recently released Les Jacobs, David Kryszajtys and Matthew McManus, Paths to Justice and the Resolution of Consumer Problems: Findings from the 2014 Everyday Legal Problems and the Costs of Justice in Canada National Survey (Toronto: Canadian Forum on Civil Justice, 2015), online: CFCJ <http://www.cfcj-

fcjc.org/sites/default/files/Paths\%20to\%20Justice\%20and\%20the\%20Resolution\%20of\%20Co nsumer\%20Problems.pdf $>$.

See further Ab Currie, "Nudging the Paradigm Shift: Everyday Legal Problems in Canada" (2016) (forthcoming); Matthew Dylag, "A Legally Pervasive Society: The Legal Problems Experienced by Ontarians" (in progress); Matthew Dylag, "Informal Justice: How Ontarians Resolve their Legal Problems" (in progress). See also Semple, "The Cost of Seeking Civil Justice in Canada", supra note 4 (making use of this national survey data set).
\end{abstract}

${ }^{15}$ This crisis has been recognized in several recent national reports. See e.g. Action Committee on Access to Justice in Civil and Family Matters, Access to Civil \& Family Justice: A Roadmap for Change, supra note 5; Canadian Bar Association, Reaching Equal Justice: An Invitation to Envision and Act, supra note 11. For a recent discussion of these trends, see Farrow, "A New Wave of Access to Justice Reform in Canada", supra note 11.

\footnotetext{
${ }^{16}$ For example, $54.3 \%$ of respondents indicated that a legal problem made daily life "extremely", "very", or "somewhat" difficult. The survey results provide further data on Canadians' experience of legal problems and their views about a problem's severity. See further Currie, "Nudging the Paradigm Shift: Everyday Legal Problems in Canada", supra note 14.
} 
Within any given three-year period, adult Canadians

experience approximately

$35,745,000$ separate everyday legal problems. multiple problems. Of those we surveyed, $30 \%$ experienced two or more legal problems. ${ }^{17}$ This means that within any given three-year period, adult Canadians experience approximately $35,745,000$ separate everyday legal problems. This suggests that the formal justice system - as it exists today would be overwhelmed if it were expected to help resolve all of the everyday legal problems experienced by the public. Further, we know from other studies and reports that people generally cannot afford to access the legal system, ${ }^{18}$ nor do they generally understand or feel welcome by it. ${ }^{19}$

\section{Problem Types}

The most frequently occurring everyday legal problems reported by respondents are consumer, ${ }^{20}$ debt, and employment problems. These are followed closely by neighbour, discrimination, and family problems. ${ }^{21}$ The percentages of people experiencing one or more problems within each problem type are shown in Figure I.

\footnotetext{
${ }^{17}$ Respondents reporting one or more problems experienced an average of 3.13 problems per individual.

18 See generally Action Committee on Access to Justice in Civil and Family Matters, Access to Civil \& Family Justice: A Roadmap for Change, supra note 5; Canadian Bar Association, Reaching Equal Justice: An Invitation to Envision and Act, supra note 11; Semple, "The Cost of Seeking Civil Justice in Canada", supra note 4.

${ }^{19}$ Farrow, "What is Access to Justice?", supra note 2 at 974.

20 For a more detailed discussion of consumer problems developed from this national survey, see Jacobs et al., Paths to Justice and the Resolution of Consumer Problems, supra note 14.
}

21 Issues included in "family" problems primarily involve "relationship breakdown" matters. Issues included in "other family" problems generally involve child related matters, including custody, guardianship, and education related issues. If all family related problems are combined ("family" and "other family"), the percentage of respondents experiencing one or more of those combined types of problems amounts to $5.1 \%$. The overall population estimate for those combined figures is $1,216,497$ Canadians $(1,093,314$ with "family law" problems, and 123,183 with "other family" problems). 


\section{Figure I: Percentage of People Experiencing One or More Legal Problems within Problem Types}

\section{Percentage of People with One or More Legal Problems}

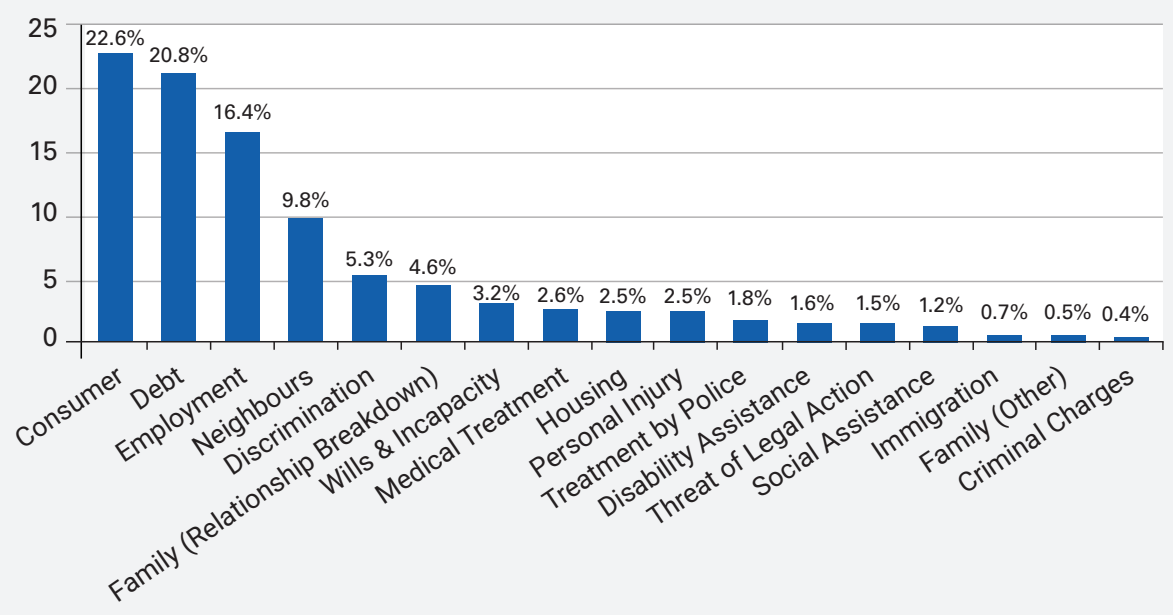

\section{Going to Law}

The study provided information on a number of issues relating to the public's use of the justice system. Respondents who reported having at least one problem (and in some cases up to seven problems) in the three-year reference period of the survey were asked a series of questions about their efforts to deal with the problem, including whether and where they sought assistance, what kind of assistance, the current status of the problem, and the impact of the problem on their life.

\section{Number of Problems}

Of the 1,321 respondents who reported on problems, 761 of them reported on two different problems, while the remaining 560 reported on a single problem. $^{22}$

\footnotetext{
22 In order to be consistent with earlier legal problems surveys, respondents who reported more than seven problems were not asked the follow up questions about how they dealt with, and the effect of, those problems on their life.
} 


\section{Service Options}

$95 \%$ of people try to do something about their legal problems.
Respondents reported using different "paths to justice" 23 when addressing their legal problems. Set out below is a summary of some of the main findings relating to how Canadians deal with and are affected by their everyday legal problems. ${ }^{24}$

- Courts and tribunals. Very few people with legal problems use the formal legal system to resolve their problems. Of those who attempted to solve their problems, approximately $7 \%$ of people reported appearing before courts or tribunals to deal with their legal problem. Instead, they used a variety of other options in their attempts to resolve the problem.

- Legal advice. Approximately $19 \%$ obtained legal advice in some form, mainly from private bar lawyers. ${ }^{25}$

- Non-legal assistance. Approximately $28 \%$ obtained assistance from an organization such as a union or an advocacy group.

- Internet. Approximately 33\% searched online for help.

- Other party. Approximately $75 \%$ contacted the other party in the dispute.

- Friends and relatives. Approximately $61 \%$ obtained advice from friends and relatives.

\section{Taking Action}

Regardless of how or where people sought help, most people try to do something about their legal problems. Of the people with legal problems, only $5 \%$ took no action to resolve the problem and most people took more than

\footnotetext{
${ }^{23}$ See further Genn, "Paths to Justice", supra note 10.

${ }^{24}$ In this overview report the respondent is the unit of analysis and, because a respondent could be asked about either one or two problems, the results can be complex. For example, a respondent who has one problem and has solved that problem is counted as having solved their problem and a respondent who has two problems and has solved both of them is also reported as having solved their problems. If one problem is solved and one is ongoing, we report a mixed result. One of the advantages of this somewhat cumbersome approach is that it allows for population estimates. An alternative strategy is to use problems as the unit of analysis; however, this makes the use of weights impossible, which would diminish the representativeness of the sample used in the analysis.

${ }^{25}$ Legal advice included private lawyers, legal aid, clinics, etc.
} 
one action in an attempt to resolve the problem. ${ }^{26}$ Among the $95 \%$ who made some attempt to resolve the problem, about one-fifth of people, $21 \%$, took only one action. Further, approximately $21 \%$ took two actions, approximately $20 \%$ took three actions, approximately $14 \%$ took four separate actions, and approximately $24 \%$ took five or more actions.

One in five $(21 \%)$ of those who reported a problem indicated that cost was a factor in their decision not to take action.

\section{Satisfaction with Options}

From the survey, it is clear that Canadians have mixed feelings about the effectiveness of their options for resolving legal problems. On the positive side, many respondents reported favourably about various sources of help.

- Legal advice. Approximately $81 \%$ reported the legal advice they obtained was helpful.

- Non-legal assistance. Approximately $68 \%$ said the non-legal assistance they received from various organizations was helpful.

- Internet. Over half (58\%) reported that information they gleaned from the internet was helpful (either very or somewhat).

- Friends and relatives. Approximately $68 \%$ reported that assistance they received from friends and relatives was helpful.

On the more negative side, despite attempts to resolve their problems, many people did not find their chosen option helpful.

- Negotiation. For example, almost half, $49 \%$, of people who attempted to solve their problem by negotiating with the other party said the attempt was not useful.

\footnotetext{
${ }^{26}$ What we understand from what we were told, and more generally, is that when people do nothing about their legal problem, it is often because, among other things (including perceived cost), they think nothing can be done about it, or that the problem is not that serious. This is an issue that would be useful ground for further research. See e.g. further Paths to Justice, supra note 10 at 106 .
} 


\section{Unresolved Problems and Issues of Fairness}

Nearly one-third (30\%) of the respondents reported their problems had not been resolved and were ongoing. The majority (55\%), however, reported that their problems had been resolved within the three-year reference period of the study. The remaining $15 \%$ of respondents reported mixed results with one problem resolved and one problem ongoing.

Many people felt that the outcome they received was unfair. Among those with problems that had been resolved, $46 \%$ said the outcome for one (or both) of their problems was unfair. Further, $70 \%$ said that the outcome they obtained did not achieve all of what they had originally expected. Among people with problems that were ongoing, $16 \%$ said the problem had become worse. Finally, among self-helpers ${ }^{27}$ who said the problem had been resolved, $42 \%$ said that, in retrospect, they felt the outcome would have been better if they had obtained some assistance. ${ }^{28}$

These results support other findings that indicate that some Canadians, particularly those with fewer resources and those who see themselves more on the margins of society, do not view the justice system as fair, accessible or reflective of them or their needs. ${ }^{29}$

\footnotetext{
${ }^{27}$ Self-helpers were defined as people who did not obtain legal assistance or assistance from some organization. The definition does not take into account whether the advice from either the legal or the non-legal sources was helpful. Self-helpers used a variety of self-help strategies, including searching the internet, negotiating with the other party, or obtaining assistance from friends or relatives. For further discussions of self-represented litigants, see e.g. the National Self-Represented Litigants Project, "Identifying and Meeting the Needs of Self-Represented Litigants, Final Report" (May 2013), online: NSRLP

$<$ https://representingyourselfcanada.files.wordpress.com/2014/05/nsrlp-srl-research-studyfinal-report.pdf>; Trevor C.W. Farrow et al., Addressing the Needs of Self-Represented Litigants in the Canadian Justice System (Toronto and Edmonton: Association of Canadian Court Administrators, 2012), online: CFCJ <http://www.cfcjfcjc.org/sites/default/files//docs/2013/Addressing\%20the\%20Needs\%20of\%20SRLs\%20ACCA \%20White\%20Paper\%20March\%202012\%20Final\%20Revised\%20Version.pdf>.

${ }^{28}$ This finding is consistent with the results of other studies that indicate that people who receive assistance are more likely to achieve greater success addressing their legal problems. See e.g. Farrow, "What is Access to Justice?", supra note 2 at 972.

${ }^{29}$ See e.g. Farrow, "What is Access to Justice?", ibid.
} 


\section{Cost of Everyday Legal Problems}

$43 \%$ of

respondents said

they spent some

money attempting

to resolve their

legal problem.

Even before this survey, we knew - at least we could assume - that the everyday legal problems experienced by the public come with a variety of costs. $^{30}$ But what costs, and how much? The most exciting, unique and challenging aspect of this survey involves our attempt to look at those specific cost of justice questions. Trying to understand what everyday legal problems cost individuals and the state, on a national scale, is a daunting task - one that has not been done before. This survey data yields important findings that provide significant insights into various aspects of those justice costs.

By way of overview, the survey included specific questions on what everyday legal problems cost the public. Those costs include money spent by people attempting to resolve their problems as well as intangible costs to individuals that are a direct consequence of experiencing a legal problem. These intangible costs can include, for example, decreasing physical health, high levels of stress and emotional problems, and strains on relationships among family members. Everyday legal problems can result in costs to the basic security of the person in terms of loss of employment or housing. They can also cost the state as the impacts of experiencing legal problems are passed on to publicly funded services and programs by way of increased health care costs, employment insurance, social services and housing subsidies arising directly as a result of people experiencing legal problems. There can also be costs to the private sector through impacts such as lost productivity.

\section{Monetary Costs Associated with Resolving Legal Problems}

How much are everyday legal problems costing Canadians in terms of monetary figures? Of those people we surveyed and who reported on the cost aspects of their problems, $43 \%$ said they spent some money attempting to resolve their problem. ${ }^{31}$ of those respondents who provided detailed

\footnotetext{
${ }^{30}$ For a brief background discussion, see Canadian Forum on Civil Justice, The Cost of Justice:
Weighing the Cost of Fair \& Effective Resolution to Legal Problems (Toronto: Canadian Forum on

${ }^{30}$ For a brief background discussion, see Canadian Forum on Civil Justice, The Cost of Justice:
Weighing the Cost of Fair \& Effective Resolution to Legal Problems (Toronto: Canadian Forum on Civil Justice, 2012), online: <http://www.cfcj-fcjc.org/sites/default/files/docs/2012/CURA_background_doc.pdf>.

31 In terms of the survey (unweighted data), 560 respondents reported spending some money. Weighted to the population, this amounts to almost 4.4 million - 4,386,612 - people who spend some money attempting to resolve their legal problem over a three-year period.
} 


\section{On an annual basis, Canadians spend just over $\$ 7.7$ billion to deal with everyday legal problems.}

information, they reported spending approximately $\$ 6,100^{32}$ when dealing with their problems. ${ }^{33}$ In Canada, this totals approximately $\$ 23$ billion over three years. ${ }^{34}$ On an annual basis this amounts to just over $\$ 7.7$ billion. Because we only asked for detailed information about two problems and $20 \%$ of respondents reported three or more problems, these figures likely underestimate the total cost Canadians spend dealing with everyday legal problems. Further, because these estimates are based not on actual receipts and documented claims, but rather on respondents' reported expenditures (as they perceived, understood, and recalled them), we present these numbers here for what they are: strong (although likely conservative) indicators of what Canadians are spending annually on their legal issues.

Nonetheless, taking these reported numbers at face value, when we put these figures in perspective, the results are quite remarkable. Individual Canadians are clearly spending a significant amount of money on everyday legal problems. By comparison, for example, the approximate spending of $\$ 6,100$ on legal problems amounts to:

- almost $10 \%$ of the average total 2012 Canadian household expenditures $(\$ 75,443)$;

- over $10 \%$ of the average 2012 Canadian household spending on goods and services $(\$ 56,279)$;

\footnotetext{
32 Of those 560 respondents who reported spending some money, 499 respondents provided an exact cost figure. After dropping 12 unusually high cost figures of $\$ 100,000$ or in some cases much more (12 figures of $\$ 100,000$ or more from 13 respondents - see infra note 33 ), the weighted data yielded a mean of $\$ 6,109.99$ for these remaining 486 respondents.
}

33 A small number of outliers - those who reported spending $\$ 100,000$ or in some cases much more to address their problem - were excluded from these calculations (see further ibid). Those respondents were excluded based on our assessment that their responses had a potentially misleading or incorrect inflating effect on average spending numbers (although we could not be sure). To use a simple example, this group of respondents potentially assessed the value of a problem with their car (a mechanical or repair problem) as the value of the entire car (the replacement value). While a problem with a car may have required a total replacement in some instances, to avoid potentially overvaluing our spending estimates, outlier responses were excluded from our average spending figures. As such, if anything, our estimates here are at the low end of what people reported spending, and are also likely at the low end of what people actually spent. Further follow up - qualitative - research on this survey group would be useful to better assess these issues and potential concerns.

34 This rounded total cost figure is based on weighted data. 
- almost as much as Canadian households spent on average in 2012 on food $(\$ 7,739)$;

- almost three times as much as Canadians spent on average in 2012 on out-of-pocket health care expenses $(\$ 2,285)$; and

- almost half as much as Canadians spent on average in 2012 on shelter $(\$ 15,811){ }^{35}$

\section{Types of Expenses}

Figure II shows the most frequent types of expenses that people incurred when they attempted to resolve their legal problems. Lawyers' fees are, perhaps unsurprisingly, the most often cited expense. However, transportation costs are a close second. People are often required to travel for appointments or appearances at courts or tribunals - and the cost, for some, can be considerable. ${ }^{36}$ This suggests that the indirect or "non-legal" costs associated with trying to resolve legal problems must be seriously considered in any attempt to evaluate the cost of accessing justice. Expenditures on such things as materials, copying and printing are third on the list, with court fees and fees for other advisors and mediators mentioned fourth and fifth in terms of frequency.

\footnotetext{
35 See Statistics Canada, The Daily, "Survey of Household Spending, 2012" (29 January 2014), online: Government of Canada <http://www.statcan.gc.ca/daily-quotidien/140129/dq140129aeng.htm>.

${ }^{36}$ See further Nicole Aylwin and Lisa Moore, Rural and Remote Access to Justice: A Literature Review (Toronto: Canadian Forum on Civil Justice, November 2015), online: CFCJ <http://boldnessproject.ruralandremoteaccesstojustice.com/wpcontent/uploads/2016/01/Rural-Remote-Lit-Review_newcoverpage.pdf>.
} 
Figure II: Percent of Respondents Paying Different Types of Expenditure

\begin{tabular}{|c|c|}
\hline Type of Expenditure & Percent \\
\hline Lawyer Fees & 22 \\
\hline Transportation & 16 \\
\hline Purchase of Materials, Copying and Printing & 13 \\
\hline Court Fees & 11 \\
\hline Other Advisors and Mediators & 10 \\
\hline Telephone, Long Distance and Fax & 5 \\
\hline Child Care and Other Household Expenses & 5 \\
\hline (Number of Respondents) ${ }^{37}$ & $(554)$ \\
\hline
\end{tabular}

\section{Spending and Outcomes}

We might assume that spending money to resolve a legal problem results in a favourable outcome. We might also assume that the more money spent, the better the outcome. Yet, our survey data suggests that these assumptions are not necessarily true for many. For example, among people who reported spending money to resolve their problem, $41 \%$ said the outcome was fair; whereas a larger percent, $61 \%$, who did not spend money reported that the outcome was fair. These numbers suggest that people who spent money to resolve their problem were less likely to think the outcome was fair. Through these findings we are not claiming that spending money to help resolve a legal problem is not helpful. However, the data does call into question potential assumptions about the links between amounts spent, perceived fairness, and outcomes.

\footnotetext{
37 If the respondent did not incur a particular expense for the first problem, they were much less likely to incur an expense for the second problem. In Figure II the percentage represents the percentage of respondents who incurred the expenses for one or both problems. Respondents who reported on two problems often reported the same types of expenses for both.
} 


\section{Related Non-Monetary Costs}

Everyday legal
problems cost the
state an estimated
$\$ 248$ million
annually in
additional social
assistance
payments.

Dealing with legal problems causes stress and financial strain for the public even for people who have adequate resources. Legal problems are often more challenging for those with fewer resources. Given that most Canadians will, at one point in their lives, experience a legal problem, struggling to deal with those problems, or failing to resolve them at all, tends to lead to other legal, social, financial and health-related problems (in addition to the direct monetary costs discussed above) ${ }^{38}$ For example, not being able to deal with a landlord who improperly evicts someone from an apartment may lead to increased personal stress, poor performance at work, family problems or breakdown, anxiety or other health related issues. Similar problems occur for people dealing with ex-spouses who refuse to pay proper support, or fighting with a credit agency over a collection issue. The list goes on. According to our survey, over half (51\%) of people who reported having a legal problem experienced stress or emotional difficulty as a direct consequence of having that problem. This amounts to over 5.7 million Canadians.

\section{Annual Costs to the State}

Everyday legal problems, as indicated above, have significant and often devastating financial and personal costs for individuals and families. Further, experiencing - and not being able to respond adequately to - everyday legal problems costs all of us (the state). Again, the challenging questions include in what way, and how much?

We estimate that the added annual costs related to receiving social assistance, a loss of employment, and physical and mental health issues - all as a direct result of experiencing one or more everyday legal problems represent major annual costs to the state, amounting to a combined total of approximately $\$ 800$ million (and perhaps significantly more). ${ }^{39}$ An overview of these approximate annual costs to the state, which are further addressed in follow up reports, ${ }^{40}$ is set out below.

\footnotetext{
38 See e.g. Action Committee on Access to Justice in Civil and Family Matters, Access to Civil \& Family Justice: A Roadmap for Change, supra note 5 at 2-5.

${ }^{39}$ See further infra notes 43 and 46.

${ }^{40}$ See e.g. Currie, "Nudging the Paradigm Shift: Everyday Legal Problems in Canada", supra note 14. These further reports will be forthcoming through the Canadian Forum on Civil Justice and will be available on the Forum's website, online: CFCJ <http://www.cfcj-fcjc.org/>.
} 


\section{Social Assistance}

Everyday legal
problems cost the
state an estimated
$\$ 450$ million
annually in
additional
employment
insurance
payments.

Everyday legal problems cost the state an estimated \$101 million annually in additional health care costs.
We estimate that everyday legal problems cost the state $\$ 248$ million annually in additional social assistance payments. From the survey, $2.1 \%$ of respondents indicated that they accessed social assistance as a direct result of experiencing a legal problem. This amounts to 238,102 people over the three-year reference period (or 79,367 people annually). The average amount of social assistance respondents reported receiving was $\$ 285.86$ per week for an average of just over 34 weeks. ${ }^{41}$ Based on these figures and weighting the data to the population, we estimate that the extra amount spent on social assistance for the three-year reference period is $\$ 745$ million, or approximately $\$ 248$ million annually.

\section{Employment Insurance}

We estimate that everyday legal problems cost the state $\$ 450$ million annually in additional employment insurance payments. An estimated $8.4 \%$ of respondents indicated that they lost employment as a direct result of experiencing a legal problem. This amounts to approximately 932,416 people over the three-year reference period, or 310,805 people annually, receiving employment insurance for an average of 21.6 weeks at an average amount of approximately $\$ 384$ per week (as reported by respondents). Based on weighted data, the result is a total estimated cost of $\$ 1.35$ billion over the three-year reference period, or approximately $\$ 450$ million annually. ${ }^{42}$

\section{Health Care}

In total, we estimate that everyday legal problems cost the state \$101 million annually in additional health care costs. ${ }^{43}$ In the survey, respondents were

\footnotetext{
${ }^{41}$ See generally Statistics Canada, The Daily, "Government Spending on Social Services" (Friday, 22 June 2007), online: Government of Canada <http://www.statcan.gc.ca/daily-quotidien/070622/dq070622b-eng.htm>.

For a further discussion, see Currie, "Nudging the Paradigm Shift: Everyday Legal Problems in Canada", ibid.

42 See generally Office of the Superintendent of Financial Services, "2015 Actuarial Report on the Employment Insurance Premium Rate" (Ottawa: Office of the Superintendent of Financial Services, 2014, modified 2015), online: Government of Canada <http://www.osfibsif.gc.ca/eng/oca-bac/ar-ra/ei-ae/pages/ei2015.aspx>. See further Currie, "Nudging the Paradigm Shift: Everyday Legal Problems in Canada", ibid.

43 This estimate for health related costs is significantly higher than our original - very conservative - estimate of approximately \$40 million annually (see preliminary "Fact Sheet", supra note 1). The $\$ 101$ million, however, is still very likely on the low end of actual spending on these services (see further infra note 46 ).
} 


\section{Approximately $40 \%$ of Canadians who reported experiencing a high level of stress or emotional problems as a consequence of a legal problem accessed the health care system one or more times in addition to their normal usage.}

asked a series of questions regarding high levels of stress, emotional problems, and/or physical problems that they experienced as a direct consequence of experiencing a legal problem (questions were asked regarding one or two legal problems). They were also asked if, as a result of these problems, they accessed the health care system more frequently than normal. For the first problem reported on, it is estimated that $65.2 \%$ of Canadians who reported experiencing a physical health problem as a consequence of a legal problem accessed the health care system one or more times in addition to their normal usage. For the second problem reported on, an estimated $81.2 \%$ of Canadians who reported experiencing a physical health problem as a consequence of a legal problem accessed the health care system one or more times in addition to their normal usage. Further, approximately $40 \%$ of Canadians on average who reported experiencing a high level of stress or emotional problems as a consequence of a legal problem accessed the health care system one or more times in addition to their normal usage. ${ }^{44}$

Respondents were not asked further details, primarily given the practical constraints of length and format of the survey. As such, we do not know exactly how many more visits occurred, and for what exact services. However, based on the survey data, as weighted to the overall population, Canadians used the health care system an estimated 5,232,582 times over the three-year reference period - or 1,744,194 more visits annually - as a direct consequence of an everyday legal problem (1,927,562 additional uses over the three-year reference period for physical health problems that are directly connected to one or two legal problems, and 3,305,020 additional uses over the three-year reference period for extreme stress or emotional problems that are directly connected to one or two legal problems).

\footnotetext{
${ }^{44}$ From the data on the first problem reported on, an estimated $65.2 \%(1,306,024)$ of people experiencing a physical health problem as a consequence of the legal problem $(2,002,304)$ accessed the health care system at least once in addition to their normal usage; and further, an estimated $41.2 \%(2,188,143)$ of people experiencing a high level of stress or emotional problems as a consequence of the legal problem $(5,309,024)$ accessed the health care system at least once in addition to their normal usage. From the data on the second problem reported on, an estimated $81.2 \%(621,538)$ of people experiencing a physical health problem as a consequence of the legal problem $(765,706)$ accessed the health care system at least once in addition to their normal usage; and further, an estimated $38.1 \%(1,116,877)$ of people experiencing a high level of stress or emotional problems as a consequence of the legal problem $(2,933,518)$ accessed the health care system at least once in addition to their normal usage.
} 
An estimated $2.7 \%$ $(100,839)$ of Canadians lose their housing every year as a direct consequence of a legal problem.
Without specific data regarding the exact nature of every additional use of the health care system, the estimate of the overall annual cost to the health care system is based on one additional physician visit for each problem for which respondents said they used the health care system more than usual. An average cost of a physician visit is $\$ 58.15$, including office visits, consultations, surgeries and diagnostic tests, but not including radiology and laboratory costs. ${ }^{45}$ Using these figures, the estimated cost of the additional use of the health care system directly resulting from experiencing a legal problem is $\$ 304.3$ million over the three-year reference period, or approximately $\$ 101$ million annually. ${ }^{46}$

\section{Housing}

An estimated $2.7 \%(100,839)$ of Canadians lose their housing every year as a direct consequence of a legal problem. A percentage of those people estimated at $3.6 \%$ ( 6,836 individuals) - rely on emergency shelters; the others rely on temporary housing with family, friends or elsewhere. Although we assume they are significant, we are not able to report on specific cost figures related to the loss of housing at this time. ${ }^{47}$

\footnotetext{
${ }^{45}$ Canadian Institute for Health Information, Physicians in Canada, 2013: Summary Report (Ottawa: Canadian Institute for Health Information, 2014) at 13, online: $\mathrm{ClHI}$

<https://secure.cihi.ca/free_products/Physicians_In_Canada_Summary_Report_2013_en.pdf>. See further Canadian Institute for Health Information, National Physician Database, 2012-2013 Data Release: Methodological Notes (Ottawa: Canadian Institute for Health Information, 2014), online: $\mathrm{CIHI}<$ https://secure.cihi.ca/estore/productFamily.htm?locale=en\&pf=PFC2675>; Canadian Institute for Health Information, "Health spending in Canada 2013" (2016), online: $<$ https://www.cihi.ca/en/spending-and-health-workforce/spending/health-spending-in-canada2013>.

${ }^{46}$ We acknowledge that these numbers are estimates and are based on various assumptions. On one hand, it is possible that the cost of some types of visits has been overestimated. For example, some health services likely cost less, on average, than a visit to a physician's office. However, we are of the view that the better understanding of these estimates is that, if anything, they are low. For example, the estimates are based on only two problems (for which detailed data was collected in the survey). We know that approximately $41 \%$ of respondents who experienced one problem experienced three or more problems, which - on this analysis, would tend to lead to additional health care visits (and costs). Further, our estimates assume only one extra health care visit for each problem (which is again likely low - at least in some cases). For a further discussion, see Currie, "Nudging the Paradigm Shift: Everyday Legal Problems in Canada", supra note 14.

47 The respondents did not indicate how much they received in housing subsidies; therefore, we do not have annual cost estimates at this time for lost housing. For a further discussion, see Currie, "Nudging the Paradigm Shift: Everyday Legal Problems in Canada", ibid.
} 


\section{Conclusion}

We are pleased to present these overview findings from the first major national legal needs study done in Canada in a number of years, ${ }^{48}$ and the first to try to take seriously the issue of the cost of everyday legal problems economic and social - to individuals and to the state. The results are significant and should be of interest to all members of the justice community.

As for the general data that we have collected on everyday legal problems and the public's experience with law and various paths to justice, some of it strengthens previous understandings about the prevalence of everyday legal problems, some of it brings new issues of marginalization and dissatisfaction into further and sharper relief, ${ }^{49}$ and all of it is playing a significant role in helping to re-orient research and policy conversations toward an understanding by justice stakeholders that we must start to understand these issues from the point of view of those who use the system - the public. ${ }^{50}$ Making this shift is a necessary, although not a sufficient, precondition for sustained access to justice reform to occur.

As for the data specifically on costs, our approach and our early findings have been influential in helping researchers and policy makers recognize the importance of cost - economic and social - in the current shifting landscape

\footnotetext{
48 See e.g. previously Currie, The Legal Problems of Everyday Life: The Nature, Extent and Consequences of Justiciable Problems Experienced by Canadians, supra note 10.

${ }^{49}$ Further reports (in progress) will explore other areas of specific interest and concern. For example, as compared to the results of previous legal problems surveys, early indications from the data suggest that problems of discrimination are on the rise. Further, for specific findings with respect to consumer issues, see the recently released Jacobs et al., Paths to Justice and the Resolution of Consumer Problems, supra note 14.

${ }^{50}$ For example, this study, together with various related earlier and underlying initiatives that we have done in preparation for this study, was referenced in both major recent national access to justice reform initiatives (and numerous other studies, policy papers and discussions as well). See e.g. CBA, Reaching Equal Justice, supra note 11 at 15, 22, 52; Action Committee on Access to Justice in Civil and Family Matters, Access to Civil \& Family Justice: A Roadmap for Change, supra note 5 at 25-26 and nn 14, 17, 76, 143, 147, 158, 160, 163 and accompanying text. See further Farrow, "A New Wave of Access to Justice Reform in Canada", supra note 11; Semple, "The Cost of Seeking Civil Justice in Canada", supra note 4. For a representative collection of further background and related studies and initiatives to-date, see Canadian Forum on Civil Justice, "Cost of Justice", online: CFCJ <http://www.cfcj-fcjc.org/cost-of-justice>.
} 
around access to justice and policy reform. ${ }^{51}$ While these reported numbers are significant, as we have indicated earlier they are also likely at the low end of what Canadians are actually experiencing in terms of their justice spending, and also in terms of the cost of legal problems on other areas of social spending. Regardless, the major conclusions derived here from these summary findings are that these reported costs are significant - not just for individuals in terms of their annual spending, but also in terms of the impact of legal problems on other areas of general social spending.

In addition to the importance of all of these findings to justice stakeholders, the results of this study should be of most interest to all of us - the public. Clearly legal problems affect everyone. The implications of dealing with them, and of not dealing with them effectively, are significant - financially and otherwise. Access to justice, and in particular the cost of an accessible (and inaccessible) justice system, needs to become a topic of widespread public deliberation. As we have seen over the past several decades with exercise, nutrition, and emotional and physical wellbeing, for example, when important social issues become matters of widespread public interest and concern (often through the media ${ }^{52}$ and ultimately to the attention of policy makers and elected officials), significant change starts to occur. Underlying and informing those debates needs to be sound research and data. We hope that the results of this study will help to inform important public discussions around access to justice and our collective legal wellbeing.

\footnotetext{
51 See e.g. CBA, Reaching Equal Justice, supra note 11 at 52; Action Committee on Access to Justice in Civil and Family Matters, Access to Civil \& Family Justice: A Roadmap for Change, supra note 5 at 17, 160, 163 and accompanying text.

${ }^{52}$ For a representative and growing collection of media reports on this study (and related issues), see Canadian Forum on Civil Justice, "Cost of Justice: Media", online: CFCJ <http://www.cfcjfcjc.org/cost-of-justice>.
} 